\title{
Awareness Towards Chain of Custody Certification in Africa: the Case of Ghana
}

\author{
Alhassan ATTAH ${ }^{1)}$, Florin IORAS ${ }^{2)}$, Jegatheswaran RATNASINGAM ${ }^{3)}$, Ioan Vasile ABRUDAN ${ }^{4)}$ \\ 1) Timber Industry Development Division, P.O. Box 738, Takoradi, Ghana; anattah@yahoo.com \\ 2) Buckinghamshire New University, Centre for Conservation and Sustainability, Queen Alexandra \\ Road, High Wycome, HP $112 \mathrm{JZ}$, England; florin.ioras@bucks.ac.uk \\ 3) University Putra Malaysia, Faculty of Forestry, 43400 UPM, Serdang, Selangor, Malaysia; jegaratnasingam@yahoo.com \\ 4) Transilvania University, Faculty of Silviculture and Forest Engineering, Sirul Beethoven 1, Brasov, Romania; abrudan@unitbv.ro
}

\begin{abstract}
Forest certification was introduced in the early 1990 s to address concerns of deforestation and forest degradation and to promote the maintenance of biological diversity, especially in the tropics. Initially pushed by environmental groups, it quickly evolved as a potential instrument to promote sustainable forest management (SFM). To date about 126,000 ha of forests have been certified by the different certification schemes in Africa, despite Africa accounting for $17 \%$ of the World's forest cover. This has been due to the lack of awareness on forest certification and the low standards of forest management in the tropics. The authors conducted a survey of representative stakeholders, in particular export timber firms in Ghana to identify why Chain of Custody certification in the Ghana Timber sector remains undeveloped. A number of 103 stakeholders were consulted. Results collated indicate that the readiness to adopt chain of custody certification among the sector was low. The lack of a national scheme was cited as the primary reasons deterring the sector from adopting certification.
\end{abstract}

Keywords: Ghana, chain of custody, national scheme, government support

\section{Introduction}

Africa is characterised by extremely diverse ecological conditions, ranging from humid forests to deserts and from mountain temperate forests to coastal mangrove swamps. Superimposed on this ecological diversity are varying degrees of human interaction, which are shaped by political and institutional arrangements, economic conditions, social and cultural settings. This mix of factors results in a dynamic landscape mosaic. Forests and woodlands, which are estimated to occupy about 650 million ha or $22 \%$ of the land area, form an integral part of this mosaic and undergo continued changes largely owing to anthropogenic factors (FAO, 2003).

African forests have fulfilled and continue to fulfil critical economic, environmental, social and cultural functions. Currently, forests and forestry in Africa are confronted by a number of problems, including a rapid decline in the forest cover, loss of biodiversity and a variety of unsustainable use that cast uncertainty on the future flow of goods and services from the forests. Hence, stakeholders at various levels are confronted with various questions relating to the current and future state of forest resources and their ability to contribute to sustainable development (FAO, 2003). This paper is intended to clarify for Ghana the following:
- the slow uptake of certification and the absence of an endorsed national standard

- the question of awareness and government leadership as against that of the NGOs

While much has been written about certification of the forest for sound management practices, there has been little examination of chain of custody certification for wood products in Africa. The authors chose Ghana as a representative case study based on Ghana's advance approach on illegal logging and trade of timber products (eg. Ghana has signed in September 2008 the Voluntary Partnership Agreement with the European Union). Voluntary partnership agreement requires timber tracking and chain of custody is one tool. Further as the timber sector is the third largest export sector after the cocoa sector, an evaluation of the status of chain of custody certification within industry was necessary. Therefore this study assessed the current opinion within the timber sector of why in Ghana the adoption of chain of custody certification among timber industry sector is low.

\section{Development of forest certification in Ghana}

Forest Certification and its associated product certification is taking a global dimension in the light of emerging issues at the various international fora such as meet- 
122

ings of the United Nation Conference on Environment and Development (UNCED), United Nations Forum on Forests (UNFF) and the International Tropical Timber Organisation (ITTO). The development of the ITTO criteria and indicators had provided a basis for SFM in the tropics/member countries of ITTO in line with its Objective 2000 (Poore, 2003). ITTO Objective 2000 encouraged member countries to attain trade in wood products from sustainably managed forest by the year 2000 . This led to a number of policy changes and the adoption of a number of guidelines for achieving SFM in member countries of ITTO to achieve SFM. This was in reaction to the alienation of governments from the FSC process that was geared towards concerns of northern consumers (Forestry Department, 1996).

Ghana signalled its intention to develop a national forest certification scheme in 1992. National standards have been developed and field tested and the current standard is the Ghana Forest Management Certification Standards and Checklist (FMCSC Version 5), published in May 2005. The Standards (FMCSC) has harmonised the Ghana Standards with the Forest Stewardship Council's (FSC) Principles and Criteria and the African Timber Organisation (ATO)/ITTO Principles, Criteria and Indicators (PCI's) for the sustainable management of African natural tropical forests (ProForest, 2005).

For Ghana a certification scheme introduction required major policy changes and resulted in the introduction of the Forest Policy of 1994 and the Forestry Development Master Plan of 1996 (Donkor, 2003). These changes were targeted at creating a balance between resource base and industry while curbing the over-exploitation and destruction of forest resources, poor forest management and unsustainable utilization of timber resources that characterized the forestry sector in Ghana (MLFM, 1996). Factors that have contributed to the unsustainable use of Ghana's forest have included a weak and outdated concession rules, poor enforcement of forestry regulations due to resource gaps and commitment of forestry personnel, inefficient forest management policies and ineffective implementation of policies and management prescriptions (MLFM, 2005).

To address these problems the government took the lead role and organised a national stakeholder forum in 1996. The forum agreed that certification should be embraced as an important tool in forest management and accountability and certification was perceived as a means of gaining access to Ghana's major markets which are environmentally sensitive. Ghana therefore viewed certification as a strategic marketing policy that would impact on Ghana's future trade in wood products. This initiative was government driven with the objective of implementing a national certification scheme. However, given the resistance to government role and the availability of resources the process became dormant.
The re-launch of the National Working Group (NWG) in 2002 and the support received from the FSC reactivated the forest certification process in Ghana. However, a constraint to this development was the perception by some stakeholders that the regional office of FSC located in Ghana and which provided office space for the NWG was casting doubts on the neutrality of the NWG. The lack of support from the central government to the NWG tends to reflect the weak political commitment of the Ghana government in advancing certification in Ghana (Teketay, 2005). Teketay (2005) identifies poor communication and weak structures for disseminating information in Ghana as a constraint to promoting forest certification.

Major progress has however been made in Ghana with the establishment of the producers group under the Global Forest Trade Network (GFTN). Four companies that account for about $40 \%$ of Ghana's timber exports are members of the producers group. The GFTN - producers group in Ghana, have received technical support from WWF-World Wide Fund For Nature and financial support from Department for International Development (UK) (DFID). It is evident from the companies engaged in the GFTN that this initiative has not targeted the small and medium-sized forestry enterprises (SMFEs) for support and engagement. This initiative has involved only the Large Scale Enterprises (LSEs) in the Ghana timber industry.

Development of forest certification has focused on the large scale enterprises. This is a reflection of the international attention in forestry that has been given to improving the conditions for large scale forest enterprises (Sun $e t$ al., 2003). In support of this the Ghanaian Government has procedures to monitor log movements through the use of a Log Measurement Conveyance Certificate (LMCC). This certificate is required to permit log haulage from forest to mill gate (ITTO, 2001). However, it is a paperbased manual system, which has made reconciliation between forest output and timber export very difficult to establish in practice. While the paper-based system, with its accompanying procedures, has increased transaction costs to industry, the Forestry Commission has had major problems in monitoring and holding field staff to account. The volume of illegal logging in the formal sector and the loss of state revenue alluded to in preceding sections result directly from these weaknesses.

\section{Economic implications}

Ghana is yet to sell any certified timber. Various interactions with buyers and distributors indicate certified timber could obtain a premium. For Ghana the issue of market access to its major market in the EU is critical. Ghana has experienced a decrease in its sales to this market (Attah et al., 2009).

There is currently no policy intervention to provide incentives for certification. However, it is envisaged that in 
the future companies that are certified could have exemptions in procedures for export of timber. At present, all timber exports from Ghana must obtain an export permit from the Timber Industry Development Division of the Forestry Commission. Since September 2006 the process has required companies to indicate their source of raw material. If companies are certified, they will not in the future be required to provide evidence of source of raw material. This can reduce the processing time of exports permits for such companies.

Compared to other African countries, Ghana exports a lot of processed wood products, but the level of value added processing is still low (Attah et al., 2010). Ghanaian companies are mainly exporters of commodity products that are price sensitive. Hence any increases in production costs lower their profitability and competitiveness. Although no studies have as yet quantified the additional cost of certification, it is obvious that, unless companies pursue value added processing, the additional cost of meeting certification requirements will be a constraint.

Companies that are embarking on certification through the GFTN and the Kumasi Wood Cluster receive some external support for their certification related activities. The Kumasi Wood Cluster was established in Ghana in November 2004. A key aim of the KWC is to pool resources together to achieve forest certification. However, these companies can run into financial difficulties when the support ends at the end of the project period. Abeney (2007) has indicated that the slow pace of certification is also attributed to the lack of a sustainable source of finance to support the work of the National Working Group on forest certification.

\section{Constraints to Development of forest certification in Ghana}

Despite efforts towards certification achievement within the last decade, Ghana is yet to see its forests certified. The following are constraints to Ghana developing and implementing a certification scheme:

- Absence of political commitment - though Ghana's Forest Certification scheme was driven by the government of Ghana in its desire to respond to its international commitments and SFM is contained in its forest policy and forestry development plan it has neither provided resources nor guidance to forest owners or industrialists in Ghana. It has also kept the ENGOs at an arms length. ENGOs have complained of lack of a consultative process on forest certification related issues in Ghana (FERN, 2005)

- Lack of clarity in the objectives of certification - Ghana appears to have shifted from putting in place a system for forest certification to a legal assurance/validation of timber system which targets improved flow of revenues to central government treasury from timber production and exports. This could be its reaction to purchasing policies being introduced by the EU and the call by donor com- munity for improved governance in the forestry sector. It is however sending out signals that could undermine Ghana's progress to Forest Certification.

- Land tenure - Land tenure under the current legislation (Act 124 of 1962) continues to be a core issue. In that land in Ghana is vested in the President. Bird et al. (2006) recognise the complexity of land and tree tenure in Ghana and report of the difficulty in gazetting the Dede Forest reserve. This forest was first proposed for gazetting in 1935 but was only gazetted twenty years later due to disputes of Land tenure. Bird et al., further cite Hawthorne et al. (1995) as stating that Dede Forest reserve has since disappeared.

- Lack of capacity in the private sector to undertake certification - the NGO community is poorly resourced and without donor funding are unable to play their watchdog role and hence affecting governance structures in the forestry sector in Ghana.

- Recognition of national schemes - Difficulty in getting national schemes to be recognised by the existing international certification schemes. Although Ghana has itself harmonised the standards with the FSC, Programme for the Endorsement of Forest Certification Schemes (PEFC), ATO/ITTO PCI's it is yet to get its standards endorsed by the FSC and PEFC. These external agencies have not been engaged in the process of harmonisation. This reflects the poor flow and exchange of information in respect of certification in Africa (Teketay, 2005).

- Lack of clarity in the type of scheme, i.e. national versus international to be used. FSC is supporting the national initiative in Ghana. However the NWG is yet to communicate to industry its strategy for certification in Ghana. The research will seek to establish industry's knowledge about forest certification, in particular of the existence and role of the NWG and the FSC national initiative.

- Communication - Poor communication of progress of forest certification in Ghana. For instance Abenney, (2007) indicate that Ghana has embarked on a stepwise approach to forest certification. He reports that two companies, namely Samartex and Ghana Primewood have developed Action Plans while three other companies, namely John Bitar Co. Ltd., Suhuma, and Ehwia Wood Products Ltd. have undertaken baseline studies. However present literature does not acknowledge Ghana as adopting a phased approach and its standards do not indicate which elements will form the phases and how many phases are to be undertaken in the proposed phased approach. This is a source of confusion in respect of communication to the market and consumers. Abreu and Simula (2004) state that clear communications, including commitment made by producers are important. Producers are also not aware that Ghana is adopting a phased approach (ITTO, 2008). This apparent lack of awareness is one of four practical challenges facing the adoption of forest certification by forest owners (Ozanne et al., 1997; Rickenbach, 2002). 
124

- Differences in the types of forest in Ghana - Reserved forests and Outside reserves. These have differences in management schemes. The existing land ownership structures inherited from the colonial period do not promote tenure security, which is a requirement for forest certification. In Ghana this poses some problem in gaining acceptance by some international schemes that require long-term ownership by the forest owner. This has legal implications and calls for review of existing laws. Secondly reviewing the laws could also infringe on the rights of the forest communities who have always had communal ownership of the land and could be a possible source of conflict unless they are effectively engaged in the reform process. The challenge for certification would be the ability for various certification schemes and standards to balance this requirement. The management plans are the responsibility of the Forest Service Division (FSD) of the Ghana Forestry Commission. Certification requires that management plans are written by the forest owners (Proforest, 2005). In a review of forest practice and certification status in Ghana, Proforest (2005) found a wide gap between current forest management (policy, planning and implementation) and the requirements of FSC and for which the writing of management plans by FSD, a public sector agency, was identified as a major gap. This review identifies the following issues:

- Financial resources to promote certification in Ghana are lacking. Forestry competes for resources with other sectors of the economy such as health and education. The private sector on the other hand prefers to invest in other sectors of the economy that has higher returns. Timber companies who may want to pursue certification will find the extra costs prohibitive since most of the companies in the Ghana forestry sector are SMEs.

- Low literacy levels in Ghana do not promote documentation, particularly for the small and medium sized enterprises. Documentation is a requirement for certification, in particular FSC certification (Attah et al., 2009).

Despite early engagement in the forest certification process in Ghana, the country is lagging behind in forest certification. To date no forests have been certified nor has Ghana traded in certified products. The slow progress in forest certification is not unique to Ghana but to tropical timber producer countries in general.

\section{Methodology}

In order to assess the current status of chain of custody certification awareness in Ghana, a survey of a random sample of various stakeholders, in particular timber firms was conducted by mail post. The study population comprised of registered timber firms in Ghana that are engaged in exports of wood products. A list of companies that hold concessions, have processing mills or have exported timber at least once since 1986 was compiled. This formed the study population.

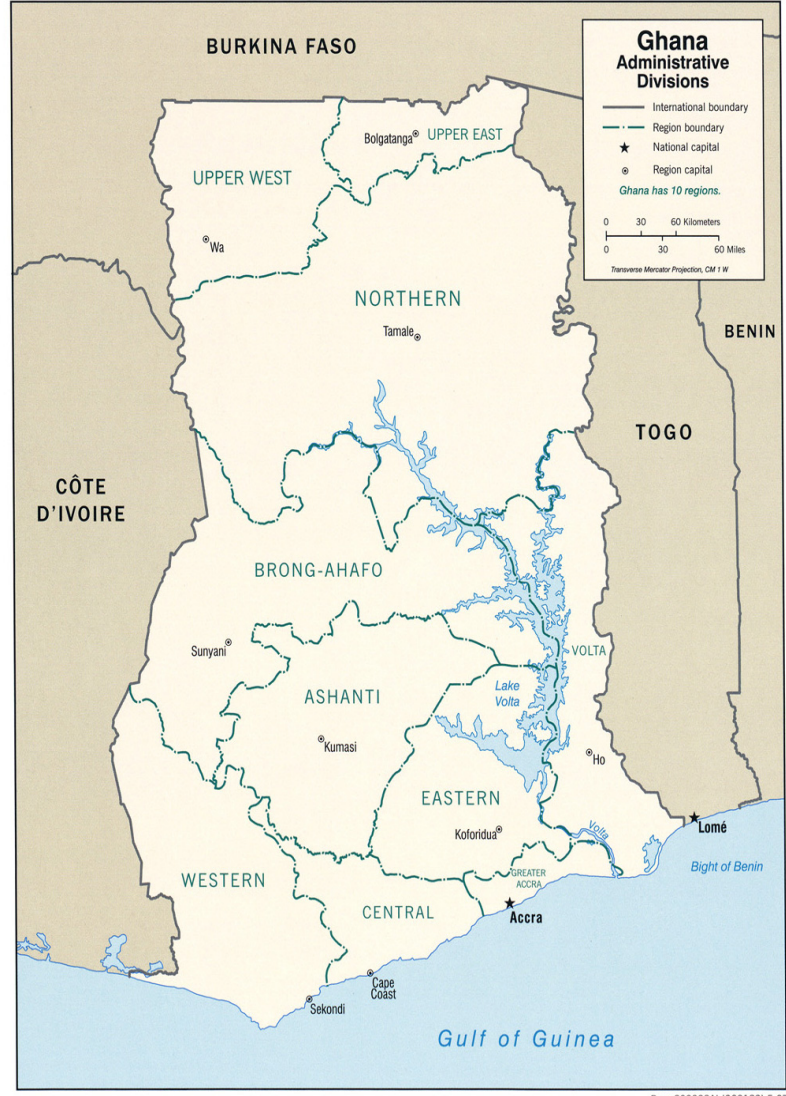

Fig. 1. Ghana administrative map

Companies were grouped into clusters based on geographic locations and sampled. Three geographic areas, namely Ashanti, Brong Ahafo and Western regions in Ghana were considered for the sample. These are part of the High Forest Zone Area (Fig. 1). The three regions were chosen because of the extent of forest concession holdings in the regions coupled with the strong presence of timber processing firms in these regions. The samples were further classified into two groups, Small and Medium Forestry Enterprises and Large Service Enterprises. Data/information was collected over a six month period in 2008 .

Prior to the implementation of the survey each firm was contacted by telephone to ensure that they are still operating businesses. The questionnaire was designed to collect information on attitudes in respect of Chain of Custody $(\mathrm{CoC})$ certification within the Ghanaian timber sector.

\section{Questionnaire development - pilot test}

A pilot test was carried out to assess the reliability of the questions using correlation to establish the level of reliability based on a score of 0.8 and above to be considered as relevant (Armor, 1974). The reliability issue was achieved with the help of multiple-item indicators.

These pilot test companies were sub- divided into SMFEs and LSEs. In the present study pilot group, the test for reliability (internal consistency) for the entire scale yield- 
Tab. 1. Reliability Coefficient scores (Cronbach's alpha value) for the sub scale of the research questionnaire

\begin{tabular}{ccc}
\hline$\#$ & Constructs/Sub Scales & Cronbach- $\alpha$ value \\
\hline 1 & Stakeholder Consultations & 0.621 \\
2 & Government support & 0.758 \\
\hline
\end{tabular}

ed a high Chronbach $-\alpha$ value (Tab1), implying that the items in the questionnaire or study instrument measured what they were supposed to measure.

The questionnaire design took onto account significant chain of custody certification factors as reported in previous studies (Volsky et al., 1998; Vidal et al., 2005; Ratnasingam et al., 2008 a, b). Two parametric statistical tests were used for inferential statistics analysis: the Standard Multiple Regression and the Independent t-test. These tests were used to test for significance among the scores from the various groups of respondents.

The rationale for the use of the parametric tests (the multiple regression and the Independent $t$-test) was based on the fact that the dependent variable on which the test for significance was computed was measured with interval scale and the distribution of mean scores is normally distributed. The data was analyzed using the Statistical Package for the Social Sciences (SPSS).

\section{Results}

103 respondent firms who participated in this study represented mainly the logging and sawmilling industries that have an export activity. Sawmills accounted for 65\% of respondents while loggers accounted for $13.6 \%$ of respondents. The two groups collectively accounted for over $75 \%$ of the respondents.

\section{Government support}

Most developing tropical countries are of the view that government should be involved within the certification process hence this section of the questionnaire sought to establish the role of government in the development of forest certification in Ghana. A recent workshop held by the UNECE, concluded that governments should remain neutral to certification schemes and serve as a moderator between schemes (FAO, 2005).

Although the extent of support from government in existing certification schemes appears quite low, the survey indicated that the situation could be better if government introduces legislation for forest certification (Mean $=4.67)$ (Tab. 2). It also emerged from the research that NGOs for instance, appear to have little role to play in the promotion of certification (Mean $=2.28)$ in Ghana. The overall relationship between government support and the pace of forest certification as well as the relationship between the defining variables of government support and the pace of forest certification indicated that support from
Tab. 2. Descriptive statistics for government support and for national scheme for forest certification and companies' pursuance of forest certification (103 respondents)

\begin{tabular}{|c|c|c|}
\hline Variables & Mean & Std. Deviation \\
\hline $\begin{array}{c}\text { Company engaged in developing } \\
\text { domestic policies }\end{array}$ & 2.61 & 1.436 \\
\hline ENGO's dominate debate on FC & 1.88 & 1.767 \\
\hline Government has key role in FC & 4.24 & 0.693 \\
\hline $\begin{array}{l}\text { Government to introduce } \\
\text { legislation for FC }\end{array}$ & 4.67 & 7.259 \\
\hline Government to facilitate FC & 4.16 & 0.711 \\
\hline $\begin{array}{l}\text { Forest certification } \\
\text { should be voluntary }\end{array}$ & 2.80 & 1.665 \\
\hline $\begin{array}{l}\text { Government must contribute } \\
\text { at least } 30 \% \text { for FC }\end{array}$ & 3.45 & 1.419 \\
\hline $\begin{array}{l}\text { Forest certification best } \\
\text { promoted by NGOs }\end{array}$ & 2.28 & 1.587 \\
\hline $\begin{array}{l}\text { National standards used } \\
\text { for forest certification }\end{array}$ & 4.10 & 0.975 \\
\hline $\begin{array}{c}\text { National standards accredited } \\
\text { to FSC/PEFC }\end{array}$ & 3.83 & 1.279 \\
\hline $\begin{array}{l}\text { Company awareness of } \\
\text { timber certification }\end{array}$ & 2.11 & 1.894 \\
\hline $\begin{array}{l}\text { FSC has best standards for } \\
\text { forest certification }\end{array}$ & 1.39 & 1.880 \\
\hline $\begin{array}{l}\text { Pan African Forest certification } \\
\text { standards used }\end{array}$ & 2.32 & 2.078 \\
\hline $\begin{array}{l}\text { Meeting certification } \\
\text { standards and added cost }\end{array}$ & 3.47 & 1.571 \\
\hline $\begin{array}{c}\text { awareness of ITTO Criteria } \\
\text { and Indicators }\end{array}$ & 1.52 & 1.857 \\
\hline
\end{tabular}

FC=Forest Certification, ENGO=Environmental NGOs

government for forest certification correlated positively but insignificantly with the dependent variable (forest certification in Ghana), $\left[R^{2}=0.104 ; \mathrm{F}(6,102)=1.849\right.$, $\mathrm{p}=\mathrm{ns}]$. This implies that the forest certification advance in Ghana is independent of the level or degree of government support. Thus, the low support from government in promoting forest certification is not responsible for the slow pace of forest certification in Ghana.

The analysis of the relationship between the various independent variables and the dependent variable (pace of forest certification in Ghana) revealed that none of the independent variables could correlate significantly with the dependent variable with the exception of the "Forest certification best promoted by NGOs" variable $(r=-0.257$, $\mathrm{p}<05$ ). The inverse relationship between NGOs' promotion of forest certification and the pace of forest certification in Ghana means that intensified action by Non Governmental Organisations in promoting forest certification reduces the slowness pace of forest certification in Ghana. This could be responsible for the higher rate of awareness in the Northern Countries where the work of the NGOs is stronger than in the tropical timber producer regions. In the tropics, NGOs are usually considered as opponents of 
126

governments and not engaged in the development of forest certification.

\section{National Standard}

This part of the questionnaire sought to establish if implementing a national scheme would promote forest certification in Ghana and encourage more companies to pursue forest certification.

A cursory look at the various mean values in Tab. 2 indicate that "national standards used for forest certification" as a single variable had more impact (Mean $=4.10)$ than the other variables in inducing or stimulating Ghanaian timber firms to pursue forest certification. The relationship between implementation of a national scheme for forest certification and companies' pursuance of forest certification in Ghana correlated positively and significantly with timber companies' pursuing forest certification in Ghana $\left[R^{2}=0.187 ; \mathrm{F}(7,102)=3.130, \mathrm{p}<.05\right]$. This implies that the tendency for more timber companies to pursue forest certification in Ghana is by far dependent on the implementation of a national scheme for forest certification. The implementation of a national scheme for forest certification will see somehow more companies pursuing forest certification in Ghana is therefore supported.

In evaluating the relationship between the independent variables within the implementation of a national scheme for forest certification model and the dependent variable (companies' pursuance of forest certification in Ghana) revealed an insignificant relationship between all the independent variables.

$79.6 \%$ of respondents indicated that national standards should be accredited to FSC or PEFC. This is a reflection that respondents view the use of national standards as means to achieving forest certification in Ghana.

\section{Conclusion}

The relatively low number of companies involved in the Chain of Custody $(\mathrm{CoC})$ process could be explained by the weak awareness and fundamental economics despite the international market demand. A high proportion of respondents purchased their raw material implying the need for an effective chain of custody system if certification is credible in Ghana. Respondents were of the view that the national standard should be accredited to either FSC or PEFC standards. This is the model that has been adopted in the UK where the UK Wood Assurance Scheme was developed and then used to seek endorsement from both FSC and PEFC. This approach has enhanced the growth of forest certification in the UK. This approach has also been used in the Scandinavian region with PEFC where national standards are used as a basis for promoting forest certification. The study therefore supports the approach to using national standards as a basis to seek endorsement for implementation of Forest certification. This approach would see the growth of forest certification in the tropics also.

This study identified that NGOs would better promote forest certification than that of governments. This is at variance with the current practice in the tropics where governments are driving and promoting forest certification. However the slow pace of development in the tropics under government guidance calls for a review in approach to provide support to NGOs in promoting forest certification in the tropics. This will however require the provision of support to develop the capacity of NGOs in Ghana and the tropical timber producing countries in general to allow for the promotion and higher rate of development of forest certification. The role of NGOs in promoting forest certification needs to increase in order to quicken the rate of growth of forest certification in Ghana and the tropical timber countries in general. Presence of a national scheme is apparent the key for $\mathrm{CoC}$ certification to be a success story in Ghana.

\section{References}

Abeney, E. (2007). Personal Communication. Lecturer, Institute of Renewable Natural Resources, wame Nkrumah University of Science and Technology, Kumasi. Ghana. aabeney@yahoo.com.

Armor, D. J. (1974). Theta Reliability and Factor Scalling. In Sociological Methodology 1973-1974, p.17-50. San Francisco, Jossey-Bass.

Attah, A., F. Ioras, I. V. Abrudan. and J. Ratnasingam (2009). The voluntary Partnership Agreement: the Ghanaian and Malaysian experience. International Forestry Review 11(3):311-318.

Attah, A., F. Ioras, J. Ratnasingam, I. V. Abrudan (2010). Chain of custody certification: an assessment of Ghanaian timber sector. European Journal of Wood and Wood Products DOI: 10.1007/s00107-009-0402-5.

José Augusto, A. K., Pinto de Abreu and Markku Simula (2004). Report on the Procedures for the Implementation of Phased Approaches to Certification in Tropical Timber Producing Countries. ITTC(XXXVII)/12.

Bird, N., T.Fomete and G. Birikorang (2006). Ghana’s Experience on Timber Verification System Design. VERIFOR country case study. Overseas Development Institute, London.

Donkor, B. N. (2003). Evaluation of government interventions in Ghana’s Forest product Trade: A post-Intervention Impact Assessment and Perception of Marketing Implications. A dissertation presented to the Louisiana State University, USA.

FAO (2003). FAOSTAT-the FAO's on-line statistical database for agriculture, fisheries and forestry, available at: http:// faostat.external.fao.org.

FAO (2005). Forest Certification: Do Governments Have a Role? 29 September 2005, Salle XIX. 27-30 September 
2005 Palais des Nations, Geneva, Switzerland.

FERN (2005). Forest Governance in Ghana, available at http:// www.illegal-logging.info/uploads/Forest_Governance_in_ Ghana.pdf.

Forestry Department (1996). Problems and potentials of applying certification to forest management in Ghana, presented at the Workshop on Forest Certification and other market-based instruments in Ghana, FORIG, Fomesua. 1213 June 1996.

Hawthorne, W. D., M. Abu-Juam (1995). Forest Protection in Ghana. IUCN Forest Conservation Programme 14.

ITTO (2008). Developing forest certification: Towards increasing the comparability and acceptance of forest certification systems worldwide. ITTO Technical Series \#29 at http://www.ardot.fi/Documents/TS29.pdf.

ITTO (2001). Market report, 1st to 15th July. ITTO, Yokohama, Japan.

MLFM (1996). Forestry Development Master Plan 1996-2010. Ministry of Lands, Forestry and Mines, Accra, Ghana.

MLFM (2005). VPA discussion paper 1. The True Cost of Legal Timber. Ministry of Lands, Forestry and Mines, Accra, Ghana.

Ozanne, L. K. and R. Vlosky (1997). Willingness to pay for environmentally certified wood products: A consumer perspective. Forest Products Journal 47(6):39-48.

Poore, D. (2003). Changing Landscapes, Earthscan Publications Ltd.
ProForest (2005). Review of the Kumasi Wood Cluster Partnership Project. ProForest. Oxford.

Ratnasingam, J., T. H. Macpherson and F. Ioras (2008 a). An assessment of Malaysian wooden furniture manufacturers' readiness to embrace chain of custody (COC) certification. Holz Roh Werkst.

Ratnasingam, J., T. H. Macpherson, F. Ioras and I. V. Abrudan (2008 b). Chain of custody certification among Malaysian wooden furniture manufacturers: status and challenges. International Forestry Review 10 (1): 23-28

Rickenbach, M. G. (2002). Practical challenges to forest certification on small ownerships. Journal of Forestry $100(9): 43-47$.

Sun, C. and X. Chen (2003). Small and Medium Forestry Enterprises in China: An initial review of sustainability and livelihoods issues. Research Centre of Ecological and Environmental Economics, Beijing, China and International Institute of Environment and Development, London.

Teketay, D. (2005). Status of forest resources, trends in forest certification an FSC in Africa. FSC Stakeholders Workshop. Elmina, Ghana.

Vidal, N., R. Kozak and D. Cohen (2005). Chain of custody certification: an assessment of the North America solid wood sector. For Policy Econ 7(3):345-355.

Vlosky, R. P. and L. K. Ozanne (1998). Environmental certification of wood products: The US manufacturers' perspective. For Prod J. 48(9):21-26. 